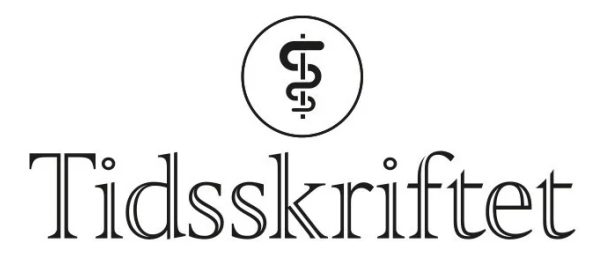

DEN NORSKE LEGEFORENING

\title{
Rastløse bein og kirurgi: ikke enten eller
}

KOMMENTAR

\section{ALFRED ARVESEN}

alfarve@online.no

Alfred Arvesen er overlege, spesialist i karkirurgi og generell kirurgi, Aleris.

\section{PER HENRIK ZAHL}

Ingen av forfatterne har oppgitt noen interessekonflikter.

Vi er enig med Einar Kinge (11) i at pasienter med rastløse bein også burde utredes for venøs insuffisiens og for aterosklerose. Dette burde forfatterne av artikkelen «Rastløse bein - en studie fra allmennpraksis» (므) diskutert og derfor skrev vi vårt leserbrev.

Vi er ikke enige med Einar Kinge i at «det er viktig å forstå at det dreier seg om to forskjellige tilstander med forskjellig patofysiologi og symptombilde».

For det første, det femte diagnosekriteriet om «andre åpenbare årsaker» er ikke så åpenbart. Selv erfarne klinikere kan miste en nevrovaskulær, venøs diagnose uten ultralyd. Jeg har sett tenåringer med venøs svikt i fem hovedstammer uten en eneste synlig åreknute. Selv store, insuffisiente leggperforanter og laterale, subdermale plexus kan lett overses ved inspeksjon av underekstremiteter forfra eller i liggende stilling.

For det andre, hvis $14 \%$ av nordmenn har rastløse ben (므), så vil hver fjerde av disse samtidig også ha venøs insuffisiens, (3) hvis det ikke er noen kobling mellom sykdommene. Denne undergruppen har da to sykdommer med nesten like symptomer (bortsett fra at en stor andel av dem med venøs insuffisiens vil ha en varierende grad av åreknuter). Derfor bør veldig mange undersøkes for venøs insuffisiens. Hvis langt flere enn hver fjerde har venøs insuffisiens, burde man tenke i retning av syndrom og felles forklaring.

For det tredje, veneklaffer finnes også i små i kar med diameter fra 100 mikrometer til $2 \mathrm{~mm}$ (4). Dersom klaffesvikt i svært små kar kan utløse ulcus cruris, kan dette i teorien også forårsake diffus perifer nevropati og parestesier så vel i armer som i bein. Dette er en hypotese, som vi kaller «mikrovenøs hypertensiv nerveskade», og ligger i grenselandet karpatofysiologi og nevrovaskulær dysfunksjon. Dette burde noen forske på.

Behandlingen av rastløse bein synes å være bestemt av hvilken spesialist man blir sendt til. Kirurgi er billig og effektivt ( $92 \%$ rapporter å bli kvitt sine symptomer) (5). Behandling med medisiner er derimot lite effektivt siden man må prøve en rekke forskjellige medisiner. Gabapentin/ pregabalin (førstevalg), dopaminagonister (annetvalg) og oksykodon + 
nalokson (tredjevalg). Disse har mange bivirkninger, og oksykodon er sterkt vanedannende og en viktig årsak til en opioidepidemi med reseptpliktige legemidler i USA (ㅁ). Vi tror mange med rastløse bein (ikke alle) kunne ha nytte av en utredning for venøs insuffisiens.

\section{REFERENCES}

1. Kinge E. Rastløse bein og kirurgi. Tidsskr Nor Legeforen 2022;142. doi:10.4045/tidsskr.22.0062. [CrossRef]

2. Bjorvatn B, Wensaas KA, Emberland KE et al. Rastløse bein - en studie fra allmennpraksis. Tidsskr Nor Legeforen 2021; 141. doi: 10.4045/tidsskr.21.0333. [PubMed][CrossRef]

3. Hamdan A. Management of varicose veins and venous insufficiency. JAMA 2012;308: 2612-21. [PubMed][CrossRef]

4. Bollinger A, Leu AJ, Hoffmann U et al. Microvascular changes in venous disease: an update. Angiology 1997; 48: 27-32. [PubMed][CrossRef]

5. Shah S. Study establishes association between reflux of lateral subdermic plexus and restless leg syndrome. Venous News 21.11.2019. https://venousnews.com/reflux-lateral-subdermic-plexus-restlessleg-syn. Lest 1.2.2022.

6. National Institute on Drug Abuse. Overdose Death Rates. 20.1.2022. https://nida.nih.gov/drugtopics/trends-statistics/overdose-death-rates. Lest 1.2.2022.

Publisert: 28. februar 2022. Tidsskr Nor Legeforen. DOI: 10.4045/tidsskr.22.0104

(C) Tidsskrift for Den norske legeforening 2023. Lastet ned fra tidsskriftet.no 26. april 2023. 